\author{
맥종간 혼파재배시 생육, 조사료 생산성 및 사료가치 비교 \\ 주정일 · 이승수 · 유지홍*·이정준**·박기훈**·이희봉***
}

\title{
Seed Blending Effect on Growth, Yield and Feed Value among Four Winter Cereals for Whole Crop Silage
}

\author{
Jung II Ju, Seung Su Lee, Ji Hong Yoo*, Joung Jun Lee**, Ki Hun Park** \\ and Hee Bong Lee***
}

\begin{abstract}
The overwintering crops, barley, wheat, oat and triticale etc, have been received in korea as high-quality roughage for round-baled silage making as livestock feed. Studies were carried out to evaluated the effects of seed blending on growth, yield and feed value between barley and wheat, triticale and oat, respectively. The results are summarized as follows: The barley was declined in the growth and spike's size as affected by sown as mixed seeding with triticale, but not effected with oat. The total fresh yield were increased by grown as mixed seeding with wheat, triticale and oat, but the dry matter yield were not significantly increased because of the low percentage of dry matter and the decrease of barley's growth. The neutral detergent fiber (NDF) and crude protein content were increased by seed blending, but acid detergent fiber (ADF) and digestible dry matter (DDM) content were decreased. The feed value was improved by seed blending of barley and wheat, but not significant at seed blending of triticale and oat. Because of the flourishing tillers, difference of heading date and abundant leaves of oat, the optimum crop for mixed seeding with barley for increment of forage productivity was oat in middle area of korea.
\end{abstract}

(Key words : Seed blending, Whole crop silage, Feed value)

$$
\text { I. 서 론 }
$$

최근 수입 조사료 및 배합사료 가격이 지속 적으로 상승됨에 따라 축산 농가에서는 사료작 물의 재배 확대를 통한 조사료 자급 및 경영비 절감이 절실히 요구되고 있다. 이의 대책으로 겨울철 휴한지에 재배가 가능한 동계작물 즉 청보리, 총체밀, 호밀, 트리티케일(라이밀) 그리 고 월동재배가 가능한 귀리 등이 유망한 작물
로 대두되고 있다.

혼파는 두 종류 이상의 작물 종자를 함께 섞 어서 뿌리는 방식으로 입지공간의 효율적 이 용, 비료성분의 합리적 이용, 잡초발생의 경감, 재해에 대한 안정성의 증대 및 가축사료 영양 의 균형적 이용 등의 이점이 있다. 일반적으로 화본과 작물과 두과작물을 혼파하는데, 근계분 포 차이로 인한 토양수분 및 양분의 효율적 이 용, 두과작물에 의한 질소고정 작용으로 토양

충남농업기술원 (Chungnam Provincial ARES, Yesan 340-861, Korea)

* 충북농업기술원 (Chungbuk Provincial ARES, Cheongweon 363-883, Korea)

** 호남농업연구소 (Honam Agricultural Research Institute, NICS, RDA, Iksan 570-080, Korea)

*** 충남대학교 (Chungnam, National Univ. Daejeon, 305-764. Korea)

Corresponding author: Hee Bong Lee, Chungnam, National Univ. Daejeon 305-764, Korea.

Tel: +82-42-821-5727, E-mail: hblee@cnu.ac.kr 
중 질소에 대한 경합 회피, 조사료의 조단백질 함량 증대 및 사료가치 향상, 도복방지 및 생 산성 향상 등의 효과를 기대할 수 있다 (Pisulewska 등, 1989, 김 등 2002, Ta 및 Faris, 1987, Caballero 등, 1995). 화본과 작물과 화본 과 작물의 혼파재배에 관한 보문으로 이 및 이 (2006)는 상번초형 (tall type)와 잔디형 (turf type) 혼파초지의 건물수량과 사료가치를 비교 검토한 바 있고, 김 및 김 (1999)은 오차드그라 스를 주품종으로 하는 혼파초지에 이탈리안 라 이그라스 또는 켄터키 블루그라스를 보조 초종 으로 혼파했을 때 생육 및 잡초발생에 대한 효 과를 구명하였으며, 김 및 강 (1974)은 오차드 그라스와 라디노 클로버를 조합한 혼파초지에 보조 초종으로 이탈리안 라이그라스의 파종량 을 증가시켰을 때 효과를 구명한 바 있고, 이 등 (2004)은 tall fescue, kentucky bluegrass 및 perennial ryegrass 중심의 하번초형 혼파조합간 에 건물수량, 화학적 성분, 건물소화율 및 영양 소 수량을 보고한 바 있다. 한편 조 등 (1979) 은 겉보리 품종간 혼합비율에 따라 주요 특성 간에 상호 보완작용이 큰 조합을 선발한 바 있 고, 고 등 (2002)은 사료용 옥수수 후작으로 사 초용 연맥과 호밀의 혼파재배시 생산성, 사료 가치 및 적정 혼파 비율을 구명한 바 있으며, Stoskopf (1981)는 호밀품종의 조만성에 따른 차 이를 보고한 바 있다.

조사료를 최대로 생산하기 위해서는 도입작 물의 생리 생태적 특성이 상이한 작물간 또는 품종간 혼파재배가 고려되고 있다. 청보리 전 용 품종의 생산성을 보완할 수 있는 작물로는 같은 시기에 생육하면서도 출수와 등숙이 늦은 작물인 밀, 트리티케일, 월동 귀리 등이 유리할 것으로 판단된다. 이들 작물은 청보리 다수확 재배시 보조 작물로서 간장, 출수기, 분얼력 및 생장반응의 차이에 의한 작물간 경합을 유도함 으로써 조사료 생산성을 보완할 수 있을 것으 로 판단된다.

따라서 본 시험은 논에서 조사료 최대생산을
위하여 청보리를 주품종으로 하고, 밀, 트리티 케일, 귀리등과의 혼파재배시 생육, 생산성 및 사료가치 등을 비교하여 분석코자 하였다.

\section{ㅍ. 재료 및 방법}

본 시험에 사용된 재료는 수확시기가 비슷하 지만 생육특성이 서로 상이한 보리 ‘영양’, 밀 ‘금강', 트리티케일 ‘신영’, 귀리 ‘삼한’ 등 4종 의 동계작물에 대하여 조사료를 최대로 생산할 수 있는 혼파조합과 이들에 대한 적정 혼파비 율을 구명코자 충남지역 소재 예산군 신암면 소재 충남농업기술원 답리작 포장에서 수행하 였다.

주작목 및 품종은 종자 채종 및 확보가 용이 한 ‘영양' 보리로 하였고, 보조품종으로는 ‘금 강' 밀, ‘신영' 트리티케일, ‘삼한’ 귀리를 시험 재료로 하였다. 시험구 처리내용은 ‘영양’보리 : 기타 총체맥류의 혼합비율을 $100: 0,70: 30$, $50: 50,0: 100 \%$ 등으로 하였다. 파종은 2006년 10 월 18 일에 실시하였고, 파종량은 총 파종량 이 $20 \mathrm{~kg} / 10 \mathrm{a}$ 로 되도록 각 비율에 따라 해당량 을 혼합하였다. 시비량은 토양분석 후 진단 시 비처방 기준에 준하였는데 $\mathrm{N}-\mathrm{P}_{2} \mathrm{O}_{5}-\mathrm{K}_{2} \mathrm{O}=13.0$ $6.5-3.5 \mathrm{~kg} / 10 \mathrm{a}$ 이었다. 이중 질소는 기비 대 추 비를 $50: 50$ 으로 나누어 분시하였는데 추비는 3월 9일에 실시하였고, 인산과 칼리는 전량 기 비로 시용하였다. 재배방법은 휴폭 $150 \mathrm{~cm} \times$ 파 폭 $120 \mathrm{~cm} \times$ 휴장 $6 \mathrm{~m}$ 로 하여 휴립광산파 하였 다.

수확기는 보리보다 생육단계가 늦은 밀, 트 리티케일, 귀리 등의 수확기에 예취하면 보리 가 완숙되어 가축 이용성이 떨어지므로 주작목 인 ‘영양' 보리의 황숙기인 5월 29일에 전 시 험구를 예취하였다. 이 때 밀은 출수 후 25일 로서 호숙기 상태 이었고, 트리티케일은 출수 후 23일로 유숙기가 지난 상태이며, 귀리는 출 수 후 16일로 유숙기에 해당하였다. 생육조사 는 보리 황숙기에 초장, 간장, 수장, 이삭수, 생 
체중 및 건물율을 각각 조사하였다. 예취면적 은 $6.0 \mathrm{~m}^{2}(1.5 \times 4 \mathrm{~m})$ 이었고, 이 중 생체 $500 \mathrm{~g}$ 정도를 취하여 건물율을 조사한 후 건물수량을 계산하였다. $\mathrm{ADF}$ (Acid detergent fiber), $\mathrm{NDF}$ (Neutral detergent fiber) 함량은 Van soset법을 이용하여 분석하였고, DDM 함량은 미국초지학 회의 $\mathrm{DDM}(\%)=88.9-0.779 \times \mathrm{ADF}$ 의 공식을 이용하였으며, 상대적 사료가치 $(\mathrm{RFV}$, Relative feed value $)$ 는 $\mathrm{RFV}=\mathrm{DDM}(\%) \times(120 / \mathrm{NDF}) / 1.29$ 의 계산식을 이용하여 산출하였다.

\section{III. 결과 및 고찰}

\section{1. 총체맥류의 작물학적 특성 비교}

Table 1에서 보는 바와 같이 ‘영양’ 보리의 출수기는 ‘금강' 밀, ‘신영' 트리티케일, ‘삼한’ 귀리에 비하여 각각 8 일, 10 일, 20 일 빨랐다. 이삭길이는 ‘영양' 보리가 총체맥류 중 가장 작았고 밀, 트리티케일, 귀리 순으로 컸다. 간 장과 수장의 합인 초장은 '영양' 보리에 비하 여 ‘금강' 밀이 $3.5 \mathrm{~cm}$ 작았고, '신영' 트리티케 일이 $26.9 \mathrm{~cm}$, ‘삼한' 귀리가 $9.0 \mathrm{~cm}$ 이상 컸다. 잎의 크기는 ‘영양' 보리에 비하여 ‘삼한'귀리 가 가장 컸고, 다음은 ‘신영’ 트리티케일이며, 그 다음은 '금강' 밀 이었다. 이탈리안 라이그 라스나 톨페스큐 등 목초에서 많이 사용하는 풍엽성의 개념으로 보면 풍엽성은 귀리 > 트리 티케일 > 밀 > 보리 순으로 양호했다.

따라서 ‘영양' 보리와 비교할 경우 ‘금강' 밀 은 내한성이 강하고 초장과 생육특성이 비슷한
것으로 간주할 수 있고, 트리티케일은 내한성 과 내재해성이 강할 뿐만 아니라 출수기 및 간 장의 차이에 의한 광 이용효율 측면에서 장점 이 있을 것으로 판단되며, 귀리는 내한성이 상 대적으로 약하여 월동 후 고사주율이 많고 고 엽율이 높아 생육재생이 늦지만 보리의 생육이 유숙기 까지 진행된 후에 귀리가 출수되고 그 이후에 생장이 급격히 진행되므로 출수기와 생 육단계의 차이에 의한 양분과 광 이용효율 측 면에서 유리할 것으로 판단된다.

보리, 밀, 트리티케일 및 귀리 등 각 작물의 수량구성요소 및 종실수량을 비교한 결과 (Table 2), 이삭수는 트리티케일이 가장 적었고, '삼한' 귀리가 ‘영양' 보리에 비하여 월등히 많았다. 그러나 일수립수는 보리가 가장 많았고, “신영' 트리티케일이 비슷하였으며, ‘금강' 밀과 '삼한’ 귀리가 가장 적었다. 조곡수량은 ‘영양’ 보리가 가장 많았고, ‘신영’ 트리티케일, ‘금강' 밀, ‘삼 한' 귀리 순이었다. 이들 공시재료 중 ‘금강' 밀은 일수립수와 조곡수량이 일반적인 인식과 달리 적었는데 이는 4월 상순의 저온으로 피해 가 발생하여 불임립이 많이 발생하였기 때문인 것으로 판단된다.

\section{2. 보리와 밀의 혼파 비율에 따른 생육 및 수량성}

Table 3에서 보는 바와 같이 보리는 밀과 혼 파하면 간장, 수장 및 100 개의 지상부 건물중 이 감소하는 경향이었으나 밀은 보리와의 혼합 비율이 낮아질수록 간장은 작아지는 경향을 보

Table 1. Comparison of growth characteristics among barley, wheat, triticale and oat for forage use grown by seed blending

\begin{tabular}{|c|c|c|c|c|c|c|c|}
\hline \multicolumn{2}{|c|}{ Species } & \multirow{2}{*}{$\begin{array}{c}\text { Heading } \\
\text { date }\end{array}$} & \multirow{2}{*}{$\begin{array}{c}\text { Maturing } \\
\text { date }\end{array}$} & \multirow{2}{*}{$\begin{array}{l}\text { Culm length } \\
(\mathrm{cm})\end{array}$} & \multirow{2}{*}{$\begin{array}{l}\text { Spike length } \\
(\mathrm{cm})\end{array}$} & \multicolumn{2}{|c|}{ Leaf $(\mathrm{cm})$} \\
\hline Crop & Variety & & & & & Length & Width \\
\hline Barley & Youngyang & 26 April & 31 May & 95 & 4.3 & 14.3 & 1.6 \\
\hline Wheat & Geumkang & 4 May & 8 June & 87 & 8.8 & 18.1 & 1.0 \\
\hline Triticale & Shinyoung & 6 May & 11 June & 116 & 10.2 & 22.9 & 1.2 \\
\hline Oat & Samhan & 16 Мау & 11 June & 91 & 17.3 & 25.1 & 1.0 \\
\hline
\end{tabular}


Table 2. Comparison of yield component and rough grain yield among barley, wheat, triticale and oat for forage use grown by seed blending

\begin{tabular}{|c|c|c|c|c|c|}
\hline \multicolumn{2}{|c|}{ Species } & \multirow{2}{*}{$\begin{array}{c}\text { No. of spike } \\
\text { per } \mathrm{m}^{2}\end{array}$} & \multirow{2}{*}{$\begin{array}{l}\text { 1,000-grain } \\
\text { weight (g) }\end{array}$} & \multirow{2}{*}{$\begin{array}{l}\text { No. of grains } \\
\text { per spike }\end{array}$} & \multirow{2}{*}{$\begin{array}{c}\text { Rough grain } \\
\text { yield }(\mathrm{kg} / 10 \mathrm{a})\end{array}$} \\
\hline Crop & Variety & & & & \\
\hline Barley & Youngyang & 571 & 28.4 & 49.3 & 670 \\
\hline Wheat & Geumkang & 685 & 45.6 & 20.1 & 513 \\
\hline Triticale & Shinyong & 513 & 32.0 & 42.1 & 551 \\
\hline Oat & Samhan & 1,072 & 25.8 & 20.8 & 481 \\
\hline
\end{tabular}

Table 3. Comparisons of growth characteristics according to different seed blending ratio between barley and wheat for whole crop forage use at paddy field

\begin{tabular}{cccccccc}
\hline \multirow{2}{*}{$\begin{array}{c}\text { Seed blending } \\
\text { (Barley : Wheat) }\end{array}$} & $\begin{array}{c}\text { Culm } \\
\text { length } \\
(\mathrm{cm})\end{array}$ & $\begin{array}{c}\text { Spike } \\
\text { length } \\
(\mathrm{cm})\end{array}$ & $\begin{array}{c}\text { 100-plant } \\
\text { weight } \\
(\mathrm{g})\end{array}$ & & $\begin{array}{c}\text { Culm } \\
\text { length } \\
(\mathrm{cm})\end{array}$ & $\begin{array}{c}\text { Spike } \\
\text { length } \\
(\mathrm{cm})\end{array}$ & $\begin{array}{c}\text { 100-plant } \\
\text { weight } \\
(\mathrm{g})\end{array}$ \\
\hline \hline $100: 0$ & 96 & 4.4 & 217 & & - & - & - \\
$70: 30$ & 93 & 4.3 & 205 & & 78 & 7.2 & 184 \\
$50: 50$ & 93 & 4.0 & 206 & & 87 & 8.0 & 176 \\
$0: 100$ & - & - & - & & 84 & 7.1 & 177 \\
\hline
\end{tabular}

였고 100 개 줄기와 이삭의 건물중은 높아지는 경향이었다. 따라서 보리와 밀은 작물간 경합 이 발생하였는데 ‘영양’ 보리가 ‘금강’ 밀에 의 하여 간장이 작아지고 지상부 식물체의 건물중 이 감소되는 등 생육이 저하된 것으로 판단되 었다. 한편, 조 등(1979)은 겉보리 두 품종간 혼파재배에서 간장의 변화가 발생하였으나 그 차이는 미미하였다고 보고하였는데 본 시험에 서는 보리와 밀 등 서로 다른 작물이 공시되어 그 경향 역시 차이가 있을 수 있을 것으로 판 단되었다.

종자 혼합비율을 달리하여 파종했을 때 보리 와 밀의 이삭수를 조사한 결과(Table 4), 보리 단작 파종이 밀 단작 파종에 비하여 이삭수가 적었다. '영양' 보리와 ‘금강' 밀을 $70: 30$ 비 율로 파종하면 이삭수는 보리 단작 파종에 비 하여 $23 \%$ 많아졌고 이때 비율은 보리: 밀 = $70: 30$ 로서 종자 혼합비율과 같은 경향이었다. 보리와 밀을 50 대 50 비율로 혼합하여 파종하 면 총이삭수는 ‘영양' 보리 단작 파종에 비하
여 $21 \%$ 많아졌고, 이때 보리와 밀의 이삭수 비 율은 $53: 47$ 로서 보리의 비율이 약 3\% 더 많 아졌다. 따라서 보리와 밀을 혼합하여 파종하 면 보리 단작에 비하여 총 이삭수가 많아지는 효과가 있었다. 한편 조 등(1979)은 포장도복과 좌절하중이 다른 품종을 혼파재배하면 상호 보 완작용 효과가 있다고 하였는데 본 시험에서는 포장도복이 발생하지 않아 그 효과를 확인할 수가 없었다.

예취한 시험시료에서 일정량을 채취한 다음 보리와 밀을 구분하고 각 작물별로 줄기에서 이삭을 절단한 다음 각 부위별로 건조한 후 건 물중으로 계산한 이삭과 줄기 건물중의 구성비 율은 Table 5 과 같다.

보리 단작 파종시 지상부에서 이삭이 차지하 는 비율이 $61.1 \%$ 이었으나 보리의 혼합비율이 $50 \%$ 로 낮아지면 $59.9 \%$ 로 지상부에서 이삭이 차지하는 비율이 약 $0.2 \%$ 감소되었다. 따라서 보리와 밀을 혼합할 때 보리의 혼합비율이 낮 아지고 밀이 높아지면 보리가 밀에 비하여 경 
Table 4. Comparison of number of spikes according to different seed blending ratio between barley and wheat for whole crop forage use at paddy field

\begin{tabular}{ccccc}
\hline Seed blending & \multicolumn{4}{c}{ No. of spikes per $\mathrm{m}^{2}$} \\
\cline { 2 - 5 } (Barley : Wheat) & Barley & Wheat & Total & Index \\
\hline \hline $100: 0$ & 495 & 0 & $495^{\mathrm{b}}$ & 100 \\
$70: 30$ & 427 & 183 & $609^{\mathrm{a}}$ & 123 \\
$50: 50$ & 316 & 284 & $600^{\mathrm{a}}$ & 121 \\
$0: 100$ & 0 & 645 & $645^{\mathrm{a}}$ & 130 \\
\hline
\end{tabular}

* Means within a column followed by the same letter are not significant by duncan's multiple range test at the $5 \%$ level.

Table 5. Dry matter distribution between spikes and culm according to different seed blending ratio between barley and wheat for whole crop forage use at paddy field

\begin{tabular}{cccccc}
\hline Seed blending & \multicolumn{2}{c}{ Barley } & & \multicolumn{3}{c}{ Wheat } \\
\cline { 2 - 4 } \cline { 5 - 6 } (Barley : Wheat) & Spike & Culm & & Spike & Culm \\
\hline \hline $100: 0$ & 61.1 & 38.9 & & - & - \\
$70: 30$ & 61.1 & 38.9 & & 45.5 & 54.5 \\
$50: 50$ & 59.9 & 40.1 & & 44.4 & 55.6 \\
$0: 100$ & - & - & & 42.9 & 57.1 \\
\hline
\end{tabular}

합력이 다소 약해 보리의 이삭크기가 다소 작 아지고 건물 축적이 감소되는 것으로 나타났 다. 한편, 밀은 보리와 반대로 보리와 혼파하면 오히려 지상부에서 이삭이 차지하는 비율이 높 아지는 것으로 나타났다.

‘영양’ 보리와 ‘금강' 밀의 종자 혼합비율을 달리하여 파종한 후 보리 황숙기에 생체수량과 건물수량(Table 6)을 조사한 결과, 청예수량은 ‘영양' 보리 단작 파종에 비하여 ‘금강' 밀 단 작 파종이 약 $7.6 \%$ 증수되었다. '영양' 보리와 ‘금강' 밀을 70 대 30 비율로 혼합하여 파종하
면 청예수량은 보리 단작 파종에 비하여 $11 \%$ 증수되었고, 50 대 50 비율로 혼합하여 파종하 면 $14 \%$ 증수되었다. 반면에 건물수량은 보리 단작 파종에 비하여 밀 단작 파종이 약 $7.1 \%$ 감수되었다. '영양' 보리와 '금강' 밀을 70 대 30 비율로 혼합하여 파종하면 건물수량은 보리 단작 파종에 비하여 $6 \%$ 감소되었고, 50 대 50 비율로 혼합하여 파종하면 $1 \%$ 감소되었다. 생 체수량은 밀이 보리에 비하여 많았으나 건물수 량은 보리가 밀에 비하여 많았는데 이는 보리 황숙기에 예취한 관계로 생육단계가 빠른 보리

Table 6. Forage fresh and dry matter yield according to different seed blending ratio between barley and wheat for whole crop forage use at paddy field

\begin{tabular}{cccccc}
\hline \multirow{2}{*}{$\begin{array}{c}\text { Seed blending } \\
\text { (Barley }: \text { Wheat) }\end{array}$} & Fresh & Index & $\begin{array}{c}\text { Percentage of dry } \\
\text { matter }\end{array}$ & Dry matter & Index \\
\cline { 2 - 6 } & $2,681^{\mathrm{a}}$ & 100 & 41.6 & $1,116^{\mathrm{a} *}$ & 100 \\
$70: 0$ & $2,696^{\mathrm{a}}$ & 111 & 35.3 & $1,049^{\mathrm{a}}$ & 94 \\
$50: 50$ & $3,056^{\mathrm{a}}$ & 114 & 36.2 & $1,107^{\mathrm{a}}$ & 99 \\
$0: 100$ & $2,885^{\mathrm{a}}$ & 108 & 36.1 & $1,042^{\mathrm{a}}$ & 93 \\
\hline \hline
\end{tabular}

* Means within a column followed by the same letter are not significant by duncan's multiple range test at the $5 \%$ level. 
가 밀에 비하여 건물률이 상대적으로 높았기 때문이다. 즉 ‘영양' 보리와 ‘금강' 밀을 혼파하 면 보리 황숙기에 수확하게 되어 상대적으로 생육단계가 늦은 밀의 수분 함량이 높아 생체 수량은 증수되지만 건물수량에서 증수효과는 없는 것으로 나타났다. 또한 본 시험에서는 밀 의 경우 4월 상순의 저온으로 수확기에 불임립 이 일부 관찰되었는데 이것이 밀의 종실수량에 영향을 주어 보리와 밀과의 혼파에 의한 증수 효과가 나타나지 않은 것으로 판단되었다.

Table 7에서 보는 바와 같이 $\mathrm{ADF}$ 함량은 보 리와 밀 단작 파종에서 비슷하였고, $\mathrm{NDF}$ 함량 은 보리가 밀보다 높았으며, 조단백질 함량은 밀이 보리보다 높았다. 따라서 보리와 밀을 혼 파하였을 때 NDF와 DDM(Digestible dry matter) 는 보리 단작보다 감소되는 경향이었고, 조단 백질 함량과 상대적 사료가치는 증가하는 경향 이었다. 권 등(2008)은 출수 후 예취일수가 같 을 때 조단백질 함량, $\mathrm{ADF}$ 및 $\mathrm{NDF}$ 함량은 보 리에 비하여 밀이 높았고, 출수 후 수확일수가 늦을수록 감소되는 경향이었다고 하였는데 본
시험에서도 비슷한 경향이었다.

3. 보리와 트리티케일의 혼파 비율에 따른 생육 및 수량성

Table 8에서 보는 바와 같이 보리는 트리티 케일과 혼파하였을 때 혼합비율이 낮아지면 간 장, 수장 및 100 개 줄기 및 이삭의 건물중이 감소하는 경향이었으나, 트리티케일은 혼합비 율이 낮아질수록 간장과 수장은 다소 작아지는 경향이고 100 개 줄기와 이삭의 건물중은 높아 지는 경향이었다. 특히 트리티케일과 보리와의 혼파에서는 밀 또는 귀리와의 혼파에 비하여 수장의 감소가 가장 컸고 이러한 결과는 곧 지 상부 건물중에 크게 영향을 미친 것으로 나타 났다.

따라서 보리에 비하여 트리티케일은 내한성 이 강할 뿐만 아니라 생육이 왕성하므로 보리 와 트리티케일의 혼파재배시 트리티케일과의 경합으로 보리의 생육이 저하된 것으로 판단되 었다. 한편 조 등 (1979)은 동일작물의 다계품

Table 7. Feed value according to different seed blending ratio between barley and wheat for whole crop forage use at paddy field

\begin{tabular}{cccccc}
\hline $\begin{array}{c}\text { Seed blending } \\
\text { (Barley : Wheat) }\end{array}$ & $\begin{array}{c}\text { ADF } \\
(\%)\end{array}$ & $\begin{array}{c}\text { NDF } \\
(\%)\end{array}$ & $\begin{array}{c}\text { CP } \\
(\%)\end{array}$ & $\begin{array}{c}\text { DDM } \\
(\%)\end{array}$ & RFV \\
\hline $100: 0$ & 19.2 & 65.0 & 6.6 & 73.7 & 105.5 \\
$70: 30$ & 22.9 & 53.1 & 6.6 & 70.8 & 124.0 \\
$50: 50$ & 24.4 & 45.2 & 7.5 & 69.6 & 143.2 \\
$0: 100$ & 19.3 & 48.7 & 8.7 & 73.7 & 140.8 \\
\hline
\end{tabular}

Table 8. Comparison of growth characteristics according to different seed blending ratio between barley and triticale for whole crop forage use at paddy field

\begin{tabular}{|c|c|c|c|c|c|c|}
\hline \multirow[b]{2}{*}{$\begin{array}{c}\text { Seed blending } \\
\text { (Barley : Triticale) }\end{array}$} & \multicolumn{3}{|c|}{ Barley } & \multicolumn{3}{|c|}{ Triticale } \\
\hline & $\begin{array}{l}\text { Culm } \\
\text { length } \\
(\mathrm{cm})\end{array}$ & $\begin{array}{l}\text { Spike } \\
\text { length } \\
(\mathrm{cm})\end{array}$ & $\begin{array}{l}\text { 100-plant } \\
\text { weight } \\
\text { (g) }\end{array}$ & $\begin{array}{l}\text { Culm } \\
\text { length } \\
(\mathrm{cm})\end{array}$ & $\begin{array}{l}\text { Spike } \\
\text { length } \\
(\mathrm{cm})\end{array}$ & $\begin{array}{l}\text { 100-plant } \\
\text { weight } \\
\text { (g) }\end{array}$ \\
\hline $100: 0$ & 96 & 4.4 & 217 & - & - & - \\
\hline $70: 30$ & 91 & 4.1 & 183 & 111 & 10.7 & 351 \\
\hline $50: 50$ & 91 & 3.5 & 114 & 99 & 9.1 & 309 \\
\hline $0: 100$ & - & - & - & 116 & 12.2 & 321 \\
\hline
\end{tabular}


종에서 간장의 차이가 $10 \mathrm{~cm}$ 내외의 차이일 때 는 재배에 지장이 없을 것이라고 하였는데 본 시험에서는 트리티케일과 보리는 서로 간장의 차이가 클 뿐만 아니라 생육하는 세력의 차이 로 밀이나 귀리에 비하여 보리의 생육이 크게 장애를 받은 것으로 보인다.

종자 혼합비율을 달리하여 파종했을 때 보리 와 트리티케일의 이삭수를 조사한 결과(Table 9), ‘영양’ 보리 단작 파종에 비하여 ‘신영’트리 티케일 단작 파종이 이삭수가 적었다.

‘영양’보리와 ‘신영’트리티케일을 70:30 비 율로 파종하면 이삭수는 '영양' 보리 단작 파 종에 비하여 $14 \%$ 많아졌고 이때 '영양' 보리와 ‘신영'트리티케일의 이삭수의 비율은 74 대 26 으로서 보리가 차지하는 비율이 약 $4 \%$ 더 많 아졌다. ‘영양' 보리와 ‘신영' 트리티케일을 50 대 50 비율로 혼합하여 파종하면 총이삭수는 ‘영양' 보리 단작 파종에 비하여 $6 \%$ 적어졌고, 이때 보리와 트리티케일의 이삭수 비율은 51 : 49로서 보리의 비율이 약 $1 \%$ 더 많아졌다. 따
라서 ‘영양’ 보리와 ‘신영’ 트리티케일을 혼합 하여 파종하면 ‘신영' 트리티케일의 분얼력이 보리에 비하여 적으므로 트리티케일의 혼파비 율이 높아질수록 전체 이삭수에서 보리가 차지 하는 비율은 증가되는 것으로 나타났다. 한편 고 등(1979)은 보리 품종간 혼파재배에서 $\mathrm{m}^{2}$ 당 이삭수와 일수립수가 각 품종간 조합에 따라 다르다고 하였는데 본 시험에서는 밀, 트리티 케일, 귀리 등 혼파되는 작물별로 이삭수, 이삭 의 크기 등에서 차이가 있었다.

예취한 시험시료에서 일정량을 채취한 다음 보리와 트리티케일을 구분하고 각 작물별로 줄 기에서 이삭을 잘라낸 다음 각 부위별로 건조 한 후 건물중으로 계산한 이삭과 줄기의 구성 비율은 Table 10 와 같다.

보리 단작 파종에 비하여 보리의 혼합비율이 $50 \%$ 로 낮아지면 보리 이삭이 차지하는 비율은 약 $2.8 \%$ 감소되는 경향을 나타내었다. 그러나 트리티케일은 단작 파종과 보리와 트리티케일 의 혼파시 이삭이 차지하는 비율에서는 변화가

Table 9. Comparison of no. of spikes according to different seed blending ratio between barley and triticale for whole crop forage use at paddy field

\begin{tabular}{ccccc}
\hline Seed blending & \multicolumn{4}{c}{ No. of spike per $\mathrm{m}^{2}$} \\
\cline { 2 - 5 } (Barley $:$ Triticle) & Barley & Triticale & Total & Index \\
\hline \hline $100: 0$ & 495 & 0 & $495^{\text {ab* }}$ & 100 \\
$70: 30$ & 419 & 146 & $565^{\mathrm{a}}$ & 114 \\
$50: 50$ & 240 & 227 & $467^{\mathrm{b}}$ & 94 \\
$0: 100$ & 0 & 376 & $376^{\mathrm{c}}$ & 76 \\
\hline
\end{tabular}

* Means within a column followed by the same letter are not significant by duncan's multiple range test at the 5\% level.

Table 10. Dry matter distribution between spikes and culm according to different seed blending ratio between barley and triticale for whole crop forage use at paddy field

\begin{tabular}{cccccc}
\hline Seed blending & \multicolumn{2}{c}{ Barley } & & \multicolumn{2}{c}{ Triticale } \\
\cline { 2 - 3 } \cline { 5 - 6 } (Barley $:$ Triticale) & Spike & Culm & & Spike & Culm \\
\hline \hline $100: 0$ & 61.1 & 38.9 & & - & - \\
$70: 30$ & 60.5 & 39.5 & & 31.3 & 68.7 \\
$50: 50$ & 58.3 & 41.7 & & 30.1 & 69.9 \\
$0: 100$ & - & - & & 31.9 & 68.1 \\
\hline
\end{tabular}


없었다. 따라서 보리와 트리티케일을 혼합할 때 보리의 비율이 낮고 트리티케일의 비율이 높아지면 보리와 트리티케일과의 경합으로 보 리는 이삭의 건물 축적이 다소 감소되는 것으 로 나타났다.

보리 황숙기에 조사한 생체수량과 건물수량 을 조사한 결과(Table 11), 청예수량은 '영양' 보리 단작 파종에 비하여 ‘신영' 트리티케일 단작 파종이 약 $17.2 \%$ 증수되었다. ‘영양' 보리 와 트리티케일을 70 대 30 비율로 혼합하여 파 종하면 청예수량은 보리 단작 파종에 비하여 $5 \%$ 증수되었고, 50 대 50 비율로 혼합하여 파 종하면 $14 \%$ 증수되었다. 건물수량은 '영양' 보 리 단작 파종에 비하여 '신영' 트리티케일 단 작 파종시 약 $6.8 \%$ 증수되었다. '영양' 보리와 ‘신영' 트리티케일을 70 대 30 비율로 혼합하 여 파종하면 건물수량은 보리 단작 파종에 비 하여 $7 \%$ 감소되었고, 50 대 50 비율로 혼합하 여 파종하면 $3 \%$ 감소되었다. 생체수량은 트리 티케일이 보리에 비하여 많았으나 건물수량은
보리가 트리티케일에 비하여 많았는데 이는 보 리 황숙기를 기준으로 예취한 관계로 보리가 트리티케일에 비하여 건물율이 상대적으로 높 았기 때문이다. 따라서 '영양' 보리와 '신영' 트 리티케일의 혼합비율을 70 대 30으로 할 때 생 체수량이 가장 증수되었지만 건물수량은 증수 효과가 없는 것으로 나타났다.

Table 12에서 보는 바와 같이 $\mathrm{ADF}$ 와 조단백 질 함량은 보리에 비하여 트리티케일이 높았 고, $\mathrm{NDF}$ 와 $\mathrm{DDM}$ 함량은 보리가 트리티케일에 비하여 높았다. 따라서 보리와 트리티케일을 혼파했을 때 $\mathrm{NDF}$ 와 $\mathrm{DDM}$ 함량은 보리 단작보 다 감소되는 경향이었고, $\mathrm{ADF}$ 함량과 조단백 질 함량은 증가하는 경향이었다. 그러나 보리 와 밀과의 혼파와는 달리 보리와 트리티케일과 의 혼파에서 상대적 사료가치는 큰 차이가 없 었다. 권 등(2008)은 출수 후 일수가 같을 때 조단백질 함량은 보리가 트리티케일에 비하여 높았고, $\mathrm{ADF}$ 와 $\mathrm{NDF}$ 함량은 트리티케일이 높 다고 하였는데 본 시험과는 다소 상이한 것은

Table 11. Forage fresh and dry matter yield according to different seed blending ratio between barley and triticale for whole crop forage use at paddy field

\begin{tabular}{cccccc}
\hline \multirow{2}{*}{$\begin{array}{c}\text { Seed blending } \\
\text { (Barley : Triticale) }\end{array}$} & Fresh wt. & Index & $\begin{array}{c}\text { Percentage of dry } \\
\text { matter }\end{array}$ & Dry matter & Index \\
\cline { 2 - 6 } & $2,681^{\mathrm{a}}$ & 100 & 41.6 & $1,116^{\mathrm{a} *}$ & 100 \\
\hline $100: 0$ & $2,827^{\mathrm{a}}$ & 105 & 36.8 & $1,039^{\mathrm{a}}$ & 93 \\
$70: 30$ & $3,047^{\mathrm{a}}$ & 114 & 35.6 & $1,086^{\mathrm{a}}$ & 97 \\
$50: 50$ & $3,143^{\mathrm{a}}$ & 117 & 33.2 & $1,045^{\mathrm{a}}$ & 94 \\
$0: 100$ & &
\end{tabular}

* Means within a column followed by the same letter are not significant by duncan's multiple range test at the 5\% level.

Table 12. Feed value according to different seed blending ratio between barley and triticale for whole crop forage use at paddy field

\begin{tabular}{cccccr}
\hline $\begin{array}{c}\text { Seed blending } \\
\text { (Barley : Triticale) }\end{array}$ & $\begin{array}{c}\text { ADF } \\
(\%)\end{array}$ & $\begin{array}{c}\text { NDF } \\
(\%)\end{array}$ & $\begin{array}{r}\text { CP } \\
(\%)\end{array}$ & $\begin{array}{r}\text { DDM } \\
(\%)\end{array}$ & \multicolumn{2}{c}{ RFV } \\
\hline \hline $100: 0$ & 19.2 & 65.0 & 6.6 & 73.7 & 105.5 \\
$70: 30$ & 26.6 & 63.9 & 6.8 & 67.9 & 98.8 \\
$50: 50$ & 28.2 & 58.5 & 8.1 & 66.6 & 105.9 \\
$0: 100$ & 28.4 & 54.4 & 9.1 & 66.5 & 113.7 \\
\hline
\end{tabular}


보리 황숙기에 수확하여 상대적으로 트리티케 일의 생육단계와 차이가 있었기 때문인 것으로 사료된다.

\section{4. 보리와 귀리의 혼파 비율에 따른 생육 및 수량성}

Table 13에서 보는 바와 같이 ‘영양' 보리는 ‘삼한’ 귀리와 혼파 할 때 혼합비율이 낮아지 면 간장, 수장 및 100 개 줄기와 이삭의 건물중 이 증가하는 경향이었고, 귀리는 그 반대로 감 소하는 경향이었다. '영양' 보리와 '삼한' 귀리 의 혼파는 밀이나 트리티케일의 혼파에 비하여 보리의 간장이나 수장의 감소가 가장 적었을 뿐만 아니라 보리 100 개 줄기의 건물중의 감소 폭도 가장 적었다. 그러나 귀리의 생육은 밀이 나 트리티케일에 비하여 가장 많이 감소되었 다. 이는 보리 대비 귀리의 출수기 차이가 밀 이나 트리티케일에 비하여 길었는데 보리의 생 육이 완전히 진행된 후에 귀리가 출수하고 생
장이 진행되는 관계로 보리의 생장에는 경합이 발생하지 않지만, 귀리는 보리의 사이에서 늦 게 생육하는 관계로 광 이용효율이 다소 떨어 지고 생육경합이 발생된 것으로 판단되었다.

종자 혼합비율을 달리하여 파종했을 때의 보 리와 귀리의 이삭수를 조사한 결과(Table 14), 귀리는 보리에 비하여 분얼력이 왕성하였다. ‘영양' 보리와 ‘삼한' 귀리를 70 : 30 비율로 파종하면 총이삭수는 보리 단작 파종에 비하여 $52 \%$ 많아졌고 이때 이삭수의 비율은 74 대 26 로서 보리 이삭수 비율이 약 $4 \%$ 높아졌다. 보 리와 귀리를 50 대 50 비율로 혼합하여 파종하 면 총이삭수는 ‘영양' 보리 단작 파종에 비하 여 69\% 많아졌고, 이때 보리와 밀의 이삭수 비 율은 51 : 49로서 보리의 비율이 약 $1 \%$ 더 많 아졌다. 따라서 보리에 귀리를 혼합하여 파종 하면 단위면적당 전체 이삭수가 많아지는 효과 가 있었는데 귀리의 혼합비율이 높을수록 귀리 의 왕성한 분얼력에 의하여 전체 이삭수의 증 대 효과가 컸다.

Table 13. Comparison of growth characteristics according to different seed blending ratio between barley and oat for whole crop forage use at paddy field

\begin{tabular}{|c|c|c|c|c|c|c|}
\hline \multirow[b]{2}{*}{$\begin{array}{l}\text { Seed blending } \\
\text { (Barley : Oat) }\end{array}$} & \multicolumn{3}{|c|}{ Barley } & \multicolumn{3}{|c|}{ Oat } \\
\hline & $\begin{array}{l}\text { Culm } \\
\text { length } \\
(\mathrm{cm})\end{array}$ & $\begin{array}{l}\text { Spike } \\
\text { length } \\
(\mathrm{cm})\end{array}$ & $\begin{array}{l}\text { 100-plant } \\
\text { weight } \\
\text { (g) }\end{array}$ & $\begin{array}{l}\text { Culm } \\
\text { length } \\
(\mathrm{cm})\end{array}$ & $\begin{array}{l}\text { Spike } \\
\text { length } \\
(\mathrm{cm})\end{array}$ & $\begin{array}{c}\text { 100-plant } \\
\text { weight } \\
\text { (g) }\end{array}$ \\
\hline $100: 0$ & 96 & 4.4 & 217 & - & - & - \\
\hline $70: 30$ & 93 & 4.4 & 228 & 81 & 15.6 & 76 \\
\hline $50: 50$ & 94 & 4.3 & 248 & 80 & 16.6 & 76 \\
\hline $0: 100$ & - & - & - & 86 & 16.8 & 87 \\
\hline
\end{tabular}

Table 14. Comparison of number of spikes according to different seed blending ratio between barley and oat for whole crop forage use at paddy field

\begin{tabular}{ccccc}
\hline Seed blending & \multicolumn{4}{c}{ No. of spikes per $\mathrm{m}^{2}$} \\
\cline { 2 - 5 } (Barley : Oat) & Barley & Oat & Total & Index \\
\hline \hline $100: 0$ & 495 & 0 & $495^{c^{*}}$ & 100 \\
$70: 30$ & 387 & 363 & $751^{\mathrm{bc}}$ & 152 \\
$50: 50$ & 342 & 496 & $838^{b}$ & 169 \\
$0: 100$ & 0 & 1,294 & $1,294^{\mathrm{a}}$ & 261 \\
\hline \hline
\end{tabular}

* Means within a column followed by the same letter are not significant by duncan's multiple range test at the $5 \%$ level. 
예취한 시험시료에서 일정량을 채취한 다음 보리와 귀리를 구분하고 각 작물별로 줄기에서 이삭을 잘라낸 다음 각 부위별로 건조한 후 건 물중으로 계산한 구성비율은 Table 15과 같다.

‘영양' 보리 단작 파종에 비하여 보리의 혼 합비율이 $50 \%$ 로 낮아지면 이삭의 비율 약 $1.3 \%$ 감소되는 경향을 나타내었다. 그러나 '삼 한, 귀리는 혼합비율이 낮아지더라도 이삭 대 줄기의 건물 중 비율에 변화가 적었다. 따라서 보리와 귀리를 혼합할 때 보리의 비율이 낮고 귀리의 비율이 높아지면 보리와 귀리와의 경합 으로 보리는 이삭의 건물 축적이 다소 감소되 는 것으로 나타났으나 밀이나 트리티케일에 비 하여 적은 것으로 나타났다.

보리 황숙기에 조사한 생체수량(Table 16)은 ‘영양' 보리 단작 파종에 비하여 ‘삼한' 귀리 단작 파종이 약 $42 \%$ 증수되었다. ‘영양' 보리 와 '삼한' 귀리를 70 대 30 비율로 혼합하여 파종하면 청예수량은 보리 단작에 비하여 약 $16 \%$ 증수되었고, 50 대 50 비율로 혼합하여
파종하면 약 $22 \%$ 증수되었다. 건물수량은 영 양’ 보리 단작 파종이 ‘삼한’ 귀리 단작 파종에 비하여 약 $9 \%$ 증수되었다. '영양' 보리와 '삼 한, 귀리를 70 대 30 비율로 혼합하여 파종하 면 건물수량은 보리 단작 파종에 비하여 약 $8 \%$ 증수되었고, 50 대 50 비율로 혼합하여 파 종하면 약 $1 \%$ 감수되었다. 생체수량은 '삼한' 귀리가 ‘영양' 보리에 비하여 많았으나 건물수 량은 ‘영양’ 보리가 ‘삼한’ 귀리에 비하여 많았 는데 이는 귀리가 보리에 비하여 건물율이 상 대적으로 낮았기 때문이다.

Table 17에서 보는 바와 같이 $\mathrm{ADF}$ 와 조단백 질 함량은 보리에 비하여 귀리가 높았고, $\mathrm{NDF}$ 와 $\mathrm{DDM}$ 함량은 보리가 귀리에 비하여 높았다. 따라서 보리와 귀리를 혼파했을 때 $\mathrm{NDF}$ 와 $\mathrm{DDM}$ 함량은 보리 단작보다 감소되는 경향이 었고, $\mathrm{ADF}$ 함량과 조단백질 함량은 증가하는 경향이었다. 그러나 보리와 밀의 혼파와는 달 리 보리와 귀리와의 혼파에서 상대적 사료가치 는 큰 차이가 없었다.

Table 15. Dry matter distribution between spike and culm according to different seed blending ratio between barley and oat for whole crop forage use at paddy field

\begin{tabular}{|c|c|c|c|c|}
\hline \multirow{2}{*}{$\begin{array}{l}\text { Seed blending } \\
\text { (Barley : Oat) }\end{array}$} & \multicolumn{2}{|c|}{ Barley } & \multicolumn{2}{|c|}{ Oat } \\
\hline & Spike & Culm & Spike & Culm \\
\hline $100: 0$ & 61.1 & 38.9 & - & - \\
\hline $70: 30$ & 60.5 & 39.5 & 49.5 & 50.8 \\
\hline $50: 50$ & 59.8 & 40.2 & 49.2 & 50.8 \\
\hline $0: 100$ & - & - & 49.0 & 51.3 \\
\hline
\end{tabular}

Table 16. Forage fresh and dry matter yield according to different seed blending ratio between barley and oat for whole crop forage use at paddy field

\begin{tabular}{cccccc}
\hline \multirow{2}{*}{$\begin{array}{c}\text { Seed blending } \\
\text { (Barley : Oat) }\end{array}$} & Fresh wt. & Index & $\begin{array}{c}\text { Percentage of dry } \\
\text { matter }\end{array}$ & Dry matter & Index \\
\cline { 2 - 6 } & $2,681^{\mathrm{c}}$ & 100 & 41.6 & $1,116^{\mathrm{ab}}$ & 100 \\
\hline $100: 0$ & $3,099^{\mathrm{bc}}$ & 116 & 38.9 & $1,206^{\mathrm{a}}$ & 108 \\
$50: 30$ & $3,271^{\mathrm{b}}$ & 122 & 33.8 & $1,106^{\mathrm{ab}}$ & 99 \\
$0: 50$ & $3,796^{\mathrm{a}}$ & 142 & 26.9 & $1,020^{\mathrm{b}}$ & 91 \\
\hline
\end{tabular}

* Means within a column followed by the same letter are not significant by duncan's multiple range test at the $5 \%$ level. 
Table 17. Feed value according to different seed blending ratio between barley and oat for whole crop forage use at paddy field

\begin{tabular}{cccccc}
\hline $\begin{array}{c}\text { Seed blending } \\
\text { (Barley : Oat) }\end{array}$ & $\begin{array}{c}\text { ADF } \\
(\%)\end{array}$ & $\begin{array}{c}\text { NDF } \\
(\%)\end{array}$ & $\begin{array}{c}\text { CP } \\
(\%)\end{array}$ & $\begin{array}{c}\text { DDM } \\
(\%)\end{array}$ & RFV \\
\hline \hline $100: 0$ & 19.2 & 65.0 & 6.6 & 73.7 & 105.5 \\
$70: 30$ & 22.6 & 64.7 & 7.0 & 71.0 & 102.1 \\
$50: 50$ & 26.3 & 60.1 & 7.4 & 68.1 & 105.4 \\
$0: 100$ & 33.7 & 58.5 & 8.6 & 62.3 & 99.1 \\
\hline
\end{tabular}

5. 보리와 밀, 트리티케일, 귀리와의 혼파효과

‘영양’ 보리를 주품종으로 하고 ‘금강’ 밀, ‘신영’ 트리티케일, ‘삼한’ 귀리와의 혼파재배시 나타난 효과를 '영양' 보리 단작 파종을 100으 로 볼 때 혼파재배시 혼합비율에 따른 상대지 수를 나타낸 것은 Table 18 과 같다.

‘금강' 밀은 ‘영양' 보리에 비하여 내한성이 강하고 간장이 비슷하였으며 출수기는 약 8 일 늦었지만 전체적인 생장속도는 '신영' 트리티 케일이나 ‘삼한' 귀리에 비하여 보리와 가장 비슷하였다. ‘영양' 보리 대 ‘금강' 밀을 70 : 30 또는 50 : 50으로 혼합하면 보리의 간장과 수장이 다소 작아졌고, 보리의 건물중이 감소 되었으나 $\mathrm{m}^{2}$ 당 전체 이삭수는 증가하였다. 전 체 생체수량은 증가되었으나 밀의 수분 함량이 높아 건물수량은 낮거나 비슷한 것으로 나타났 다.

‘신영' 트리티케일은 ‘영양' 보리에 비하여
내한성이 월등히 강하고 생육이 왕성할 뿐만 아니라 간장과 수장이 컸다. '영양' 보리와 '신 영, 트리티케일의 혼파에 의하여 $\mathrm{m}^{2}$ 당 이삭수 와 생체수량은 증가되었으나 보리의 생육이 크 게 영향을 받았고 건물중이 감소되어 건물수량 은 낮아졌다.

‘삼한' 귀리는 밀이나 트리티케일과는 달리 보리의 생장이 거의 완료된 후에 귀리가 출수 하고 그 이후에 왕성히 생장하는 것으로 나타 났다. 비록 '삼한' 귀리의 내한성이 보리에 비 하여 약하고 월동 후 생육재생이 늦는 관계로 밀과 트리티케일에 비하여 재배 안정성이 떨어 지지만 왕성한 분얼력으로 이삭수의 증가를 가 져왔을 뿐만 아니라 보리와의 혼파시 보리에 영향을 가장 적게 미쳤다. 따라서 '영양' 보리 대 ‘삼한' 귀리는 70 : 30 비율로 혼파하여 재 배할 경우 보리 파종량의 감소로 부족해진 분 얼수를 귀리가 왕성하게 보충하여 줌으로써 건 물수량이 약 $8 \%$ 증수된 것으로 나타났다. 그러

Table 18. Summary of seed blending effect between barley and wheat, triticale and oat, respectively

\begin{tabular}{cccccc}
\hline \multicolumn{2}{c}{ Seed blending } & Total no. of \\
\cline { 1 - 3 } $\begin{array}{c}\text { Combination crop } \\
\text { with barley }\end{array}$ & $\begin{array}{c}\text { Blending } \\
\text { ratio(\%) }\end{array}$ & $\begin{array}{c}\text { 100-plant weight } \\
\text { of barley } \\
\text { spikes per } \mathrm{m}^{2}\end{array}$ & $\begin{array}{c}\text { Forage fresh } \\
\text { yield } \\
(\mathrm{kg} / 10 \mathrm{a})\end{array}$ & $\begin{array}{c}\text { Dry matter } \\
\text { yield } \\
(\mathrm{kg} / 10 \mathrm{a})\end{array}$ \\
\hline \multirow{2}{*}{ Wheat } & 30 & 123 & 94 & 111 & 94 \\
& 50 & 121 & 95 & 114 & 99 \\
\hline \multirow{2}{*}{ Triticale } & 30 & 114 & 84 & 105 & 93 \\
& 50 & 94 & 53 & 114 & 97 \\
\hline \multirow{2}{*}{ Oat } & 30 & 152 & 105 & 116 & 108 \\
& 50 & 169 & 114 & 122 & 99 \\
\hline
\end{tabular}


나 귀리는 내한성이 약하므로 월동후 개체수나 고엽정도에 따라 생육재생이 다를 것이므로 품 종선정과 다양한 재배조건에 대한 연구가 필요 한 것으로 사료되었다. 한편 고 등(2002)은 옥 수수 후작으로 귀리와 호밀의 혼파하는 것이 건물수량의 증수 및 사료품질의 향상에 바람직 하다고 하였으나 건물수량이 증수되는 이유를 분석하지 않았다.

\section{IV. 요 약}

조사료 생산에 유망한 동계작물 중 보리, 밀, 귀리(월동 가능), 트리티케일(라이밀) 등 4종의 총체맥류에 대하여 보리를 주품종으로 한 혼파 재배시 조사료 생산 증대 효과를 요약한 결과 는 다음과 같다. 보리 식물체의 건물중과 이삭 크기 등으로 볼 때 혼파재배시 보리의 생육이 저하되는 작물은 트리티케일이 가장 심하였고, 다음은 밀이었으며, 귀리는 생육차이가 없었다. 보리를 주품종으로 하고 밀, 트리티케일, 귀리 등과의 혼파재배시 이삭수 증가 또는 보조작물 의 생체량 증가 등에 의하여 총 생체수량은 증 수되었으나 보조작물의 건물율이 낮아 건물수 량은 증수되지 않았다. 청보리와 밀, 트리티케 일, 귀리 등과의 혼파재배시 $\mathrm{NDF}$ 함량과 조단 백질 함량이 증가되었으나 $\mathrm{ADF}$ 함량과 $\mathrm{DDM}$ 함량은 낮아지는 경향이었다. 상대적 사료가치 는 보리와 밀의 혼파재배에서 높아졌으나, 보 리와 트리티케일, 보리와 귀리와의 혼파재배에 서는 차이가 없었다. 중부지방에서 보리와 혼 파재배시 조사료 생산 증대 가능성이 높은 작 물로는 밀이나 트리티케일에 비하여 분얼력이 왕성하고 출수기의 차이에 의한 생육단계의 상 이한 진행 등의 장점과 풍엽성이 상대적으로 양호한 귀리가 유망하였다.

\section{$\mathrm{V}$. 인 용 문 헌}

1. 고한종, 박형수, 김수곤, 김동암. 2002. 호밀품종
의 조만성과 연맥-호밀의 파종량이 혼파사초의 수량과 사료가치에 미치는 영향. 동물자원지 44 (2):239-250.

2. 권영업, 백성범, 허화영, 박형호, 김정곤, 이재은, 이충근, 신진철. 2008. 총체사료용 맥류의 생육시 기 및 식물체 부위별 사료가치 변화. 한국작물학 회지 53(2):144-149.

3. 김동암, 강태홍. 1974. Italian ryegrass의 파종비율 이 혼파초지의 수량 및 식생비율에 미치는 영향. 한축지 162):109-116.

4. 김문철, 김종하. 1999. 단파 또는 혼파 초지에서 Italian ryegrass와 Kentucky bluegrass의 잡초억제 효과. 한국초지학회지 19(37):241-250.

5. 김종근, 정의수, 윤세형, 서 성, 서종호, 박근제, 김충국. 2002. 연맥-헤어리벳치 혼파에 의한 사 료가치 및 생산성 향상 연구. 한국초지학회지 22 (1):31-36.

6. 이중해, 이인덕, 이형석. 2004. 하번초형 혼파조 합간의 건물수량, 사료가치 및 식생비율 비교연 구. 동물자원지 46(3):443-450.

7. 이형석, 이인덕. 2006. 상번초 및 잔디형 혼파초 지의 건물수량과 사료가치 비교연구. 한국초지학 회지 26(4):221-226.

8. 조장환, 정태영, 박문웅. 1979. 대맥 품종간 혼합 파종이 생육 및 수량에 미치는 영향. 한국작물학 회지 24(2):43-50.

9. Caballero, R., E.L. Goicoechea and P.J. Hernaiz. 1995. Forage yields and quality of common vetch and oat sown at varying seeding ratios and seeding rates of vetch. Field Crops Research (Spain) 41:135-140.

10. Pisulewska, E., P. Hanczakowski, and P. Pisulewski. 1989. Yield, composition and nutritive value of leaf protein concentrates from mixed forages of cereals and legumes. Anim. Feed Sci. Technol.(Netherlands) 27:117-125.

11. Stoskopf, N.C. 1981. Understanding crop production. Reston publishing company. Virginia. pp. 193-220.

12. Ta, T.C. and M.A. Faris. 1987. Species variation in the fixation and transfer of nitrogen from legumes to associated grasses. Plant Soil 98:265-274.

(접수일: 2008년 8월 4일, 수정일 1차: 2008년 8월 3 일, 수정일 2차 9월 5일, 게재확정일: 2008년 9월 19 일) 